\title{
$\nabla$
}

\section{Dermoscopic findings in female androgenetic alopecia}

\author{
Achados dermatoscópicos na alopecia androgenética feminina
}

\author{
Lya Duarte Ramos ${ }^{1}$ \\ Fabiane Castilho Bezerra ${ }^{1}$ \\ Valeria Petri ${ }^{3}$
}

\author{
Maria Cândida Nahás Santili ${ }^{1}$ \\ Maria de Fátima Maklouf Amorim Ruiz ${ }^{2}$ \\ Marisa Teresinha Patriarca ${ }^{4}$
}

\begin{abstract}
BACKGROUND: Androgenetic alopecia is the most common form of hair loss. It is a clinical entity of relevant interest and presents a significant psychosocial impact as it undermines self-esteem and quality of life in female patients due to the importance of the hair for people's facial balance.

OвJестіvE: The purpose of the present study is to evaluate dermoscopic signs in women clinically diagnosed with androgenetic alopecia.

METHOD: Observational study with 34 women between 17 and 68 years old who were diagnosed with androgenetic alopecia. All of them underwent photographic sessions with a 10x magnification dermoscope and a digital camera zoom set to 20x magnification and 40x magnification on the scalp frontal midline.

RESULTS: All patients showed miniaturization. A peripilar brown halo was found in 22 patients, honeycomb-like scalp pigmentation was found in 14 and yellow dots in only 1 patient. Recent studies show dermoscopy as the new tool for diagnosis assistance and treatment follow up in scalp disorders. Our study used an ordinary dermoscope and we evaluated several findings reported in the literature with significant clarity and easiness.

Conclusion: The dermoscope, which is used by dermatologists on a daily basis, is an excellent tool to assist in early diagnosis and assessment of therapeutic response in androgenetic alopecia.
\end{abstract}

Keywords: Alopecia; Dermoscopy; Miniaturization

Resumo: Fundamentos: Alopecia androgenética é forma mais comum de queda de cabelo. Constitui entidade clínica de interesse relevante e acarreta grande impacto psicossocial por comprometer a auto-estima e a qualidade de vida das pacientes.

Овјетіvо: Procurar os sinais dermatoscópicos comuns em mulheres com diagnóstico clínico de alopecia androgenética, visando diagnóstico precoce e melhor resposta terapêutica.

MÉTODos: Estudo observacional em 34 mulheres com idades entre 17 e 68 anos, com diagnóstico clínico de alopecia androgenética. Todas pacientes foram avaliadas e submetidas a registros fotográficos com o dermatoscópio no aumento de 10x e câmera digital no aumento de 20x e 40x na linha média frontal do couro cabeludo. RESUlTADOS: Todas as pacientes apresentaram miniaturização dos fios na área examinada. Halo castanho peripilar foi encontrado em 22 pacientes, pigmentação em favo de mel em 14 e pontos amarelos em apenas 1 paciente. Estudos recentes mostram a dermatoscopia como uma nova ferramenta no auxílio diagnóstico e acompanhamento do tratamento das desordens do couro cabeludo. Em nosso estudo utilizamos um dermatoscópio comum e avaliamos vários achados relatados na literatura com facilidade e clareza significativas.

CONCluSÃo: O dermatoscópio, instrumento de uso diário dos dermatologistas, é excelente ferramenta para auxílio no diagnóstico precoce e avaliação da resposta terapêutica na alopecia androgenética e é capaz de mostrar de forma simples sinais precoces de miniaturização capilar.

Palavras-chave: Alopecia; Dermoscopia; Miniaturização

Received on 09.09.2011

Approved by the Advisory Board and accepted for publication on 14.02.2012.

* Work performed at the Multidisciplinary Sector of Research in Female Skin Pathology of the Gynecology Department of the Escola Paulista de Medicina Universidade Federal de São Paulo (EPM-UNIFESP) - São Paulo (SP), Brazil.

Conflict of interest: None

Financial funding: None

Physician - Dermatology Trainee at the Hospital Ipiranga - Secretaria de Saúde do Estado de São Paulo - São Paulo (SP), Brazil.

Master in Dermatology by the Universidade Federal de São Paulo (UNIFESP) - Preceptor of the Psoriasis Sector of the Dermatology Department from Unifesp and the Hair and Nail Outpatient’s Clinic from the Dermatology Department of Hospital Ipiranga - Secretaria de Saúde do Estado de São Paulo - São Paulo (SP), Brazil.

Full Professor at the Dermatology Department - Escola Paulista de Medicina - Universidade Federal de São Paulo (EPM-UNIFESP) - Coordinator of the Psoriasis Vitiligo, Adolescents' Dermatology and Female Skin Pathology Unit - Escola Paulista de Medicina - Universidade Federal de São Paulo (EPM-UNIFESP) - São Paulo (SP), Brazil.

PhD in Health Sciences by the Universidade Federal de São Paulo (UNIFESP). - Coordinator of the Skin Pathology Interdisciplinary Center of the Escola Paulista de Medicina - Universidade Federal de São Paulo (EPM-UNIFESP) - São Paulo (SP), Brazil. 


\section{INTRODUCTION}

Androgenetic alopecia (AGA) is the most common form of hair loss followed by telogen effluvium. 1 It affects around $20 \%$ of women from several age groups. It is a genetic condition with dominant autosomal transmission of low penetrance in women. ${ }^{1,2}$ It is a clinical entity of relevant interest with significant impact on the quality of life of women. ${ }^{3}$

The pathogenesis involves progressive and gradual miniaturization of hair follicles. It is the transformation of terminal follicles into vellus follicles. The reduction in length of the anagen phase and in the matricial cell size occurs after successive follicle cycles, with subsequent increase of telogen follicles. ${ }^{4,5,6}$

Sensitivity to androgens is genetically determined and it is also dependant on the production of dihydrotestosterone (DHT) by the enzyme $5 \alpha$-reductase, subdivided in type I and type II. Women who are genetically predisposed to baldness have more activity of the $5 \alpha$-reductase in the hair follicle and have around four times more aromatase in the scalp compared to men. The $5 \alpha$-reductase transforms testosterone and androstenedione in estradiol and estrogen, respectively. That explains milder manifestation of baldness in women, one that usually keeps the front line with rarefaction, but with no receding hairline. ${ }^{5,7,8}$

The most common classification is the one from Ludwig, from 1977: I- lighter form with thinning on the top of the head; II- moderate form; III- severe form. ${ }^{8}$

Clinically, there is gradual and diffuse follicle rarefaction, with stronger involvement in the frontalparietal region, and the implant line in the frontal region is preserved (resembling a Christmas tree). ${ }^{9}$

The clinical condition usually increases after menopause due to the relative hyperandrogenism imposed by estrogenic insufficiency, which is typical of this stage of life.

The diagnosis is essentially clinical and it is based on patient and family history, and hair loss pattern. The existing examinations, like the pull test, trichogram and biopsy that assess baldness pattern and degree are limited. These last two are invasive and haircut is necessary as well as a surgical procedure. 10

Dermoscopy, which was once used for diagnosing pigmented lesions, is now considered a new tool in the diagnosis and management of a growing number of scalp disorders. 11 Recent studies show that certain aspects of AGA can be better assessed with the use of dermoscopy as earlier stages of this disorder go unnoticed at clinical examinations. ${ }^{10,11}$

Dermoscopic diagnosis is done by attesting the presence of follicles of different diameters, called miniaturized follicles. ${ }^{7,10,11}$ Other signs can be found, like honeycomb pigmentation, peripilar brown halo and yellow dots.

Videodermoscopy is the most common method in current studies for the assessment of scalp disorders, but it is more costly when compared to conventional dermoscopy.

AGA causes significant psychosocial impact by undermining patients' self-esteem and quality of life due to the importance of the hair for facial balance. Early diagnosis enables treatment to be started as early as possible, as lost hairs will not be recovered.

The objective of the present study is to assess dermoscopic findings which are usual in women clinically diagnosed with AGA who are under observation in our practice.

\section{MATERIALS AND METHODS}

An observational study was performed in 34 women between 17 and 68 years old diagnosed with Androgenetic Alopecia (AGA) treated at the Instituto da Pele da Universidade Federal de São Paulo UNIFESP, from May/2010 to December/2010.

Patients with diseases that initiate alopecia were excluded.

Patients were informed that they would participate in a clinical study. After acknowledging the project, they signed a Free and Clarified Consent Term according to the rules of Research and Ethics Committee at UNIFESP -EPM.

Next, a questionnaire about demographic aspects and personal medical history and family history was applied.

A Dermlite Hybrid dermoscope and a Cybershot Sony DSC-W210 12.1 megapixel camera were used with no conflict of interest.

All patients were assessed and subjected to photographic records with a 10x magnification dermoscope and a digital camera with $20 \mathrm{x}$ and $40 \mathrm{x}$ magnification on the scalp frontal midline. The dermoscopy findings were evaluated by three dermatology residents and one dermatologist at the time of the exam and later revised in photographs on the computer.

We considered miniaturization the existing hairs with different diameters in the analyzed area. Other dermoscopic patterns were assessed, e.g., a honeycomb-like pigmentation on the scalp, peripilar brown halo and yellow dots.

\section{RESULTS}

We evaluated 34 patients between 17 and 68 years old; 22 white women and 12 non-white ones.

Concerning time of the disorder progression, 18 patients reported hair loss for approximately 5 years and 16 patients for more than 5 years. Family 
and personal medical history related to the disease are described in table 1.

According to Ludwig classification, 23, 9 and 2 patients presented hair loss type I, II and III, respectively (Graph 1).

TABLE 1: Family and personal medical history, 2010

\begin{tabular}{lll}
\hline $\begin{array}{l}\text { Family and personal } \\
\text { medical history }\end{array}$ & Yes & No \\
\hline Menopause & 16 & 18 \\
Cosmetic practice & 23 & 11 \\
Family history of AAG & 24 & 10 \\
\hline
\end{tabular}

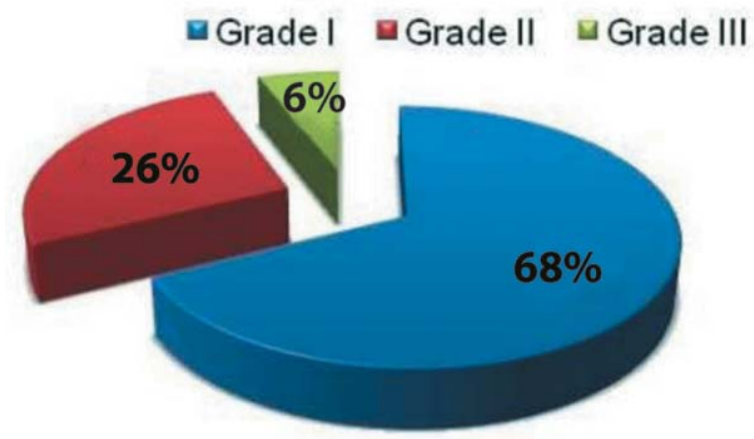

Graph 1: Ludwig's classification in relation to cases
Regarding hair appearance, 19 patients showed normal hair, 14 patients showed greasy hair and one patient showed dry hair. Scalp scaling was found in 5 patients and only one of them showed associated erythema. Pull test was negative in $79 \%$ of the patients.

Figure 1 shows the dermoscopic photographic records. All patients showed hair miniaturization in the analyzed area (Figure 1A). The honeycomb pigment was found in 14 patients and the peripilar brown halo in 22 (Figures 1B and 1C). Only 1 patient showed yellow dots (Figure 1D).

Graphic 2 shows the frequency of dermoscopy findings in our study.

\section{DISCUSSION}

Hair loss is a frequent complaint, but it is challenging for dermatologists due to the fact that therapeutic and diagnostic methods are rare.

Recent studies show dermoscopy as a new tool to help diagnosis and follow up in treatment of scalp disorders and, particularly, to improve differential diagnosis between androgenetic alopecia and chronic telogen effluvium.

Chronic telogen effluvium is a self-limited process that rarely provokes noticeable baldness, while AGA, with time, leads to a significant thickness reduction of the hair, becoming cosmetically unacceptable and psychologically frustrating. Through dermoscopy it is possible to make an early diagnosis of the disorder and minimize its dramatic evolution.
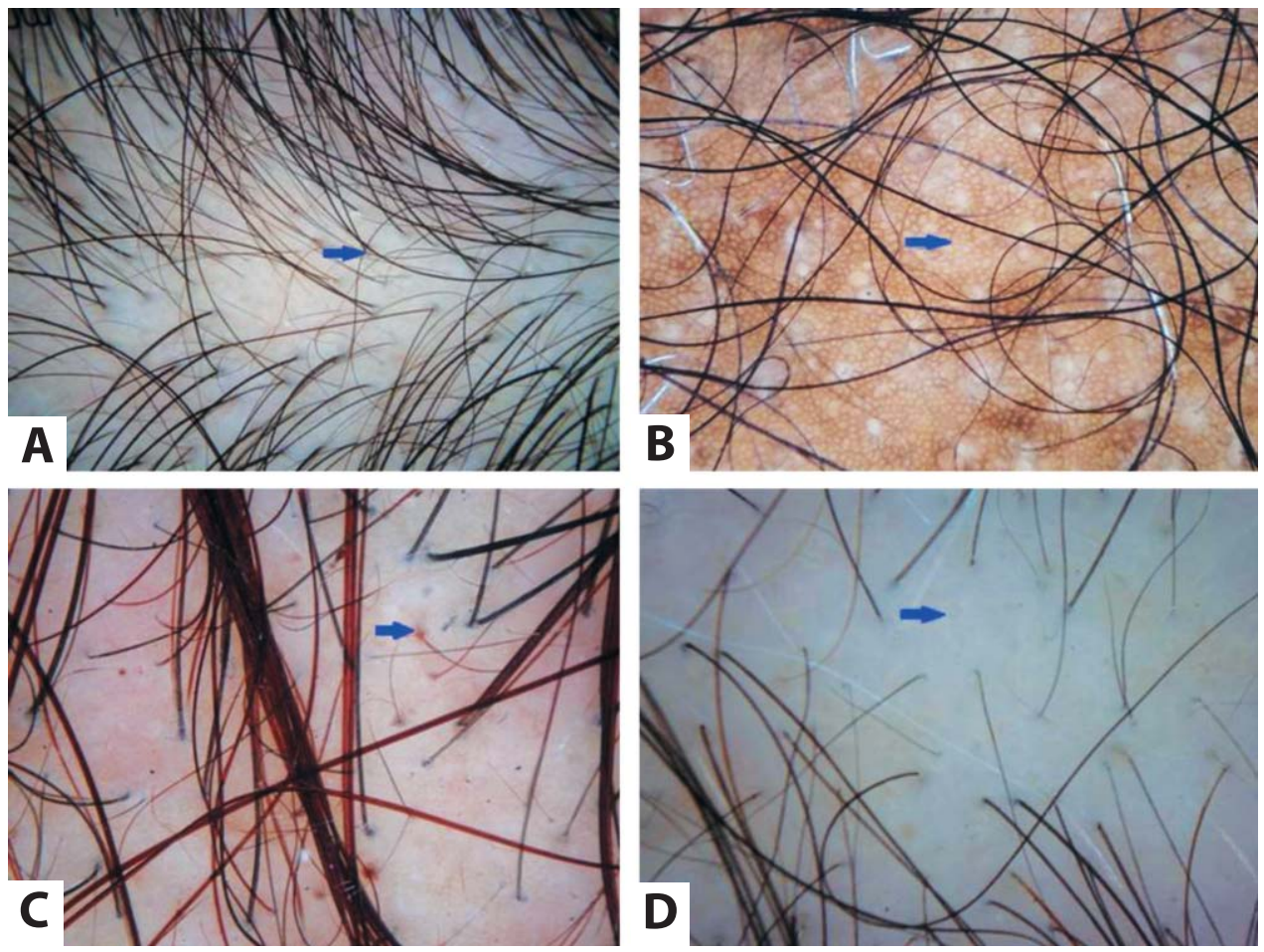

Figure 1: Dermoscopic photographic records. Dermoscopic photographic records with a $10 x$ magnification dermoscope and a digital camera with $40 \mathrm{x}$ magnification on the scalp frontal midline. 1A - Miniaturization of hair follicles, 1B - Honeycomb pigmentation, 1C - Brown peripilar halo, 1D - Yellow dots 


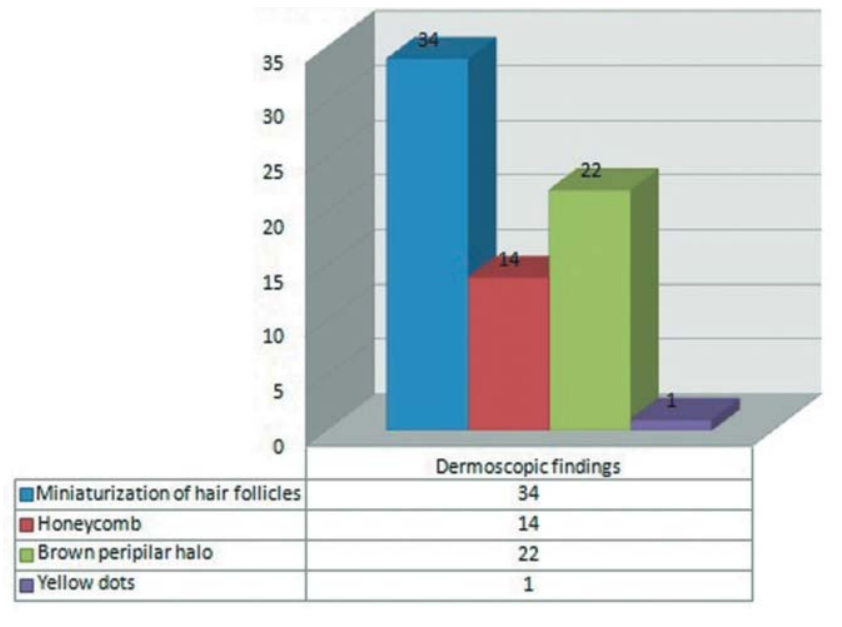

GRAPH 2: Frequency of dermoscopy findings

Using a common dermoscope we evaluated various findings reported in the literature. Such findings were very clear and significant. This low cost method does not present technical difficulties; however it is difficult to determine the percentage of hairs miniaturized in relation to the normal ones, since this is accomplished more accurately by videodermoscopy.

Dermoscopy diagnosis is done by attesting the presence of follicles of different diameters and diver- sity which are bigger than $20 \%$ (20x magnification), called miniaturized follicles. All patients evaluated showed miniaturization.

The $1 \mathrm{~mm}$ brown halo diameter in the follicular ostium reflects the presence of perifollicular lymphocytic infiltration, typical for the early stages of this disorder. According to the literature, peripilar brown halo is a distinctive sign of AGA, however, in our studies it was found only in $65 \%$ of the patients.

The honeycomb scalp pigmentation, due to sun exposure, is frequently found. ${ }^{7,11}$ It was verified in $41 \%$ of the cases.

Yellow dots are empty follicular ostium (atrichia), due to sebaceous glands persistence after severe miniaturizations of the follicles. They can be seen in other scalp disorders such as alopecia areata and alopecia incognita. ${ }^{11}$ In our study only $3 \%$ of the patients showed yellow dots, suggesting the early stage of the disorder.

\section{CONCLUSION}

The dermatoscope, a device of daily use by dermatologists, is an excellent tool to help in early diagnosis and treatment evaluation of patients with androgenetic alopecia. Moreover, it has low cost and technical practicality when compared to the videodermoscope. Furthermore, it spares the patients invasive diagnostic methods.

\section{REFERENCES}

1. Bergfeld WF. Androgenic alopecia: an autossomal dominant disorder. An J Med. 1995;98:S95-S98.

2. Filippo AA. Alopecia Androgenética Feminina. In: Kede MPV, Sabatovich 0 Dermatologia estética. São Paulo: Ed Atheneu; 2003. p.181-4.

3. Machado RB, Steiner D, Melo NR, Reis C. Desmistificando questões de eficácia e segurança no tratamento da alopecia androgenética na mulher. Femina. 2007;35:95-9.

4. Rebora A. Pathogenesis of androgenetic alopecia. J Am Acad Dermatol. 2004;50: $777-9$.

5. Vierhapper H, Maier H, Nowotny P, WaldhäusI W. Prodution Rates of Testosterona and of Dihydrotestosterona in Female Pattern Hair Loss. Metabolism. 2003;52:927-9.

6. Price VH. Androgenetic alopecia in women. J Investig Dermatol Symp Proc. 2003:8:24-7.

7. Tosti A. Dermoscopy of hair and scalp disorders: pathological and Clinical Correlation. London: Informa Healthcare; 2007. p.15-25.

8. Pereira JM. Alopecia androgenética difusa na mulher. Rev Bras Med. 1998;87-93.

9. Rutowitsch MS, Antônio JR, Steiner D, Talarico S. Alopecia androgenética. An Bras Dermatol. 1999;74:561-72.

10. Ross EK, Vincenzi C, Tosti A. Videodermoscopy in the evaluation of hair and scalp disorders. J Am Acad Dermatol. 2006;55:799-806.

11. Rakowska A, Slowinska M, Kowalska-Oledzka E, Olszewska M, Rudnicka L. Dermoscopy in female androgenic alopecia: method standardization and diagnostic criteria. Int J Trichology. 2009;1:123-30.

\author{
MAILING ADDRESS: \\ Lya Duarte Ramos \\ Rua Apiacás 559 apt 93 - Perdizes \\ CEP: 05017-020 - São Paulo, SP \\ E-mail:lya_ramos@botmail.com
}

How to cite this article: Ramos LD, Santili MCN, Bezerra FC, Ruiz MFMA, Petri V, Patriarca MT. Dermoscopic findings in female androgenetic alopecia. An Bras Dermatol. 2012;87(5):691-4. 